\title{
The Shariah Advisory Council in the Malaysian Islamic financial institutions: features and legal issues
}

\author{
Nuarrual Hilal Md. Dahlan* \\ Institute for Governance and Innovation Studies, \\ Universiti Utara Malaysia, \\ 06010 UUM Sintok, \\ Kedah Darul Aman, Malaysia \\ Email: nuarrualhilal@gmail.com \\ Email: hilal@uum.edu.my \\ ${ }^{*}$ Corresponding author
}

\author{
Ahmad Zafarullah Abdul Jalil \\ ASEAN Integration Monitoring Office (AIMO), \\ Jl. Sisingamangaraja, \\ 70A Jakarta, 12110 Indonesia \\ Email: zafarullahaj@gmail.com
}

\section{Zairani Zainol and Selamah Maamor}

Department of Muamalat and Islamic Finance,

Islamic Business School (IBS),

Universiti Utara Malaysia (UUM),

UUM Sintok, Kedah Darul Aman 06010, Malaysia

Email: zairani@uum.edu.my

Email: selamah@uum.edu.my

\begin{abstract}
The Malaysian Shariah Advisory Council ('SAC'), established under the Central Bank of Malaysia Act 2009 (Act 701), acts as an authority for the ascertainment of Islamic law in the operation of Islamic Financial Institutions ('IFIs'). Its decision is binding on all IFIs, the Bank Negara Malaysia, the Shariah Committee, the court of law and the arbitrators in Malaysia. Nonetheless, this power may be abused by the SAC to the detriment of the customer stakeholders as the SAC is immune from any legal action. This paper aims to examine the features and legal issues of the SAC. The examination uses legal research methodology. This paper finds that the immunity conferred on the SAC should be abolished and be subject to the judicial scrutiny for the benefits of the IFIs' development in Malaysia. At the ending part of this paper, the authors provide certain recommendations in regard to the issues discussed.
\end{abstract}

Keywords: Shariah Advisory Committee; SAC; Shariah Advisory Council; Malaysia; Islamic banking and financial institutions. 
Reference to this paper should be made as follows: Md. Dahlan, N.H., Jalil, A.Z.A., Zainol, Z. and Maamor, S. (2016) 'The Shariah Advisory Council in the Malaysian Islamic financial institutions: features and legal issues', J. Global Business Advancement, Vol. 9, No. 3, pp.284-298.

Biographical notes: Nuarrual Hilal Md. Dahlan is an Associate Professor of Law at the School of Law, College of Law, Government and International Studies, Universiti Utara Malaysia (UUM). Currently, he is also the Director of the Institute for Governance and Innovation Studies, UUM. His specialisations are land law, planning law, building law, housing development law, insolvency law and Islamic banking law, insofar as it relates to the issue of failed residential projects. He obtained legal qualifications from the International Islamic University Malaysia (IIUM) and Universiti Kebangsaan Malaysia (UKM). He is also an Associate Fellow of the Institute of Chartered Secretaries and Administrators (ICSA).

Ahmad Zafarullah Abdul Jalil is currently a Senior Economist at the ASEAN Integration Monitoring Office (AIMO), ASEAN Secretariat in Jakarta. Prior to joining ASEAN Secretariat, he was a Senior Manager, Economics and Market Analysis at the Securities Commission Malaysia. Earlier, he was an Associate Professor at the School of Economics, Universiti Utara Malaysia. He holds a $\mathrm{PhD}$ in Economics from the CERDI, Universite d'Auvergne France, an MSc (Economics) and BSc (Economics) from the Universite de Nancy 2, France.

Zairani Zainol is a Senior Lecturer at the Islamic Business School, College of Business, Universiti Utara Malaysia (UUM). She had been awarded a PhD in Islamic Banking from Edinburgh University, United Kingdom in 2007. Her area of interest is Islamic banking, Islamic finance, Islamic financing and Small and Medium Enterprise (SME). She has been in service for more than 16 years in Universiti Utara Malaysia.

Selamah Maamor is currently a Senior Lecturer of Islamic Economics at Department of Muamalat and Islamic Finance, Islamic Business School (IBS), Universiti Utara Malaysia (UUM). She obtained her PhD in Islamic Economics from Universiti Kebangsaan Malaysia (UKM), Bangi Malaysia in 2010. She has published in refereed journals such as Journal of Islamic Economics, Banking and Finance, Journal of Finance and Accounting, International Journal of Business and Management, Bankers Journal and Jurnal Ekonomi Malaysia. Her papers have also been presented in many international and local conferences. Her research interests include efficiency, performance and development of pawnshop, and Islamic Microfinance Institutions (IMFIs).

This paper is a revised and expanded version of a paper entitled 'Shariah Advisory Council (SAC) in the Malaysian Islamic financial institutions: features and legal issues' presented at the 11th Academy of Global Business Advancement (AGBA) World Congress, Department of Management Studies Auditorium, Institute of Technology Delhi (IIT), 20-23 November, 2014.

\section{Introduction}

Islamic banking and financial businesses in Malaysia are governed by the Islamic Financial Services Act 2013 (Act 759) (IFSA) and the Central Bank of Malaysia Act 2009 (Act 701) (CBMA). Pursuant to section 2 of the IFSA, 'Islamic banking business', 
inter alia, means the business of Islamic deposits on current account, deposit account, savings account or other similar accounts, with or without the business of paying or collecting cheques drawn by or paid in by customers and accepting money under an investment account.

The affairs and operations of Islamic banking and financial business in Malaysia are subject to the control and advice of the Shariah Advisory Committee ('SAC') under the Malaysian Central Bank (Bank Negara Malaysia) ('BNM') pursuant to the provisions under IFSA and CBMA. Apart from this, all Islamic banking and financial business operators in Malaysia are obligated to establish their respective Shariah Committees ('SC') to advise them in their affairs and operations. This is spelt out under IFSA. The SAC and SC are duty bound to apply and comply with the requirements of Shariah (Islamic Law) in dispensing with their statutory duties (section 32 of IFSA; sections $51(1), 57$ and 58 of CBMA).

\section{Issue}

The issue that this paper deals with is in regard to the immunity and superiority of the SAC. This feature is in accordance with the provisions of IFSA and CBMA. It is opined that the immunity and superiority conferred on the SAC may be abusive and can be detrimental to the rights and interests of the customer stakeholders in IFIs. There may be SAC's decisions relating to Islamic banking/financial products that are not compatible with Islamic law and equity. As the SAC is conferred with statutory immunity and superiority, no person or no court of law can correct and rectify the wrong decisions, either procedural or substantive, made by the SAC.

For an instance, Bay' Bithaman al-Ajil (BBA) (i.e., sale by deferred payment) being an Islamic banking/financial product as practised in Malaysia is legal according to the SAC. Nonetheless, the SAC fails to envisage the issue of failed housing development projects owing to the faults of the housing developers in BBA. In failed housing projects, the aggrieved purchasers who use BBA to finance the purchase of houses are still required to pay monthly instalments to the Islamic banks despite not having obtained vacant possession of the duly completed housing units and suffered various grievances. There is no term in the BBA that provides aggrieved purchasers in failed housing projects with any adequate remedies and rights against gharar (uncertainty and inability of the bank/developer to deliver duly completed house) and losses. However, under Islamic law, the vendor (the bank/developer) should ensure that the housing projects can be delivered to the purchasers. If the vendor fails to deliver duly completed houses in accordance with the specifications of the sale and purchase agreement, the vendor, being the defaulting party, should pay corresponding damages and compensation or in the worst scenario, the banks should return back all moneys received including paying compensation to the aggrieved purchasers (Md. Dahlan and Aljunid, 2010, 2011).

One of the issues relating to failed housing projects in Malaysia is this: the aggrieved purchasers in failed housing projects who obtained Islamic Home Financing through BBA are still required to settle the monthly instalments to the Islamic bank despite failure of the vendor to deliver vacant possession. If they (the purchasers) fail, they will be subject to legal actions or may be adjudged bankrupt. In this situation, in the opinion of the authors, BBA as approved by the SAC is invalid and inequitable affronting the principles of Shariah (Islamic Law). Islamic banks as the vendor should be held 
responsible if failed housing projects occur; the Islamic banks should not blame the aggrieved purchasers for the occurrences of failed housing projects due to the faults of the developers.

\section{Questions to ponder}

There are some questions that can be raised following the above elaboration, viz.,

- Whether the SAC as a statutory public authority is duty bound and under a legal responsibility in approving Islamic banking and financial products to ensure public welfare, public benefit and well-being of the customer stakeholders?

- Does the SAC as a public authority owe a legal responsibility to implement a duty to act fairly and reasonably, in good faith and observe rules of natural justice in the exercise of their power to the effect of ensuring the legality under Islamic law and equity for approving Islamic banking and financial products before the products can be applied by Islamic banks?

- If so, whether the aggrieved customers for instance the purchasers in problematic and failed housing development projects have any cause of action and/or locus standi to sue the SAC and claim appropriate remedies (legal and equitable) for all the losses and injuries they suffered and incurred for all the negligence, breach of duty to act fairly and reasonably, failure to implement fairness in the decision-making process and/or breach of natural justice and good faith in approving Islamic banking and financial products?

- Whether the ouster clauses under the IFSA and CBMA giving immunity to the SAC against any legal action can negate the power of the court for judicial review or other equitable relief?

\section{Objectives}

The objectives of this paper are as follows:

- to examine the extent of legal liability and responsibility of the SAC toward the stakeholder customers in approving Islamic banking and financial products

- to make certain recommendations insofar as the issue of legal liability and responsibility of the SAC in approving Islamic banking and financial products is concerned for the benefit and welfare of the stakeholders (for example the purchasers in housing development projects).

\section{The statutory provisions relating to the SAC}

The obligation to comply with Shariah (Islamic Law) in all the activities of the institutions carrying out Islamic banking business is clearly spelt out in section 28 IFSA. Section 28(1) IFSA (Duty of Institution to Ensure Compliance with Shariah) provides as follows: 
"An institution shall at all times ensure that its aims and operations, business, affairs and activities are in compliance with Shariah".

Similarly this obligation is spelt out in section 28(2) IFSA, which reads:

"For the purposes of this Act, a compliance with any ruling of the Shariah Advisory Council (SAC) in respect of any particular aim and operation, business, affair or activity shall be deemed to be a compliance with Shariah in respect of that aims and operations, business, affair or activity".

The word 'institution' in the above provision means an authorised person or operator or a designated payment system (section 27 IFSA). While the words 'authorised person means a person licensed under section 10 or approved under section 11 to carry on an authorised business (section 2 IFSA). The word 'operator' and 'designated payment system' are, respectively, defined as 'any person, acting alone or under an arrangement with another person, responsible for the rules, procedures and operations of a payment system' and 'a payment system prescribed as a designated payment system under subsection 39(1) (section 2 IFSA).

Sections 10 and 11 IFSA meanwhile deal specifically on the grant of licence by the Minister and Approval by the Bank.

An institution carrying out Islamic banking/financial business is under a responsibility to do certain acts once it found that the business that it carries out has contravened Shariah. The responsibility to act is prescribed by section 28(3) IFSA. Section 28(3) reads:

"Where an institution becomes aware that it is carrying on any of its business, affair or activity in a manner which is not in compliance with Shariah or the advice of its Shariah committee or the advice or ruling of the SAC, the institution shall -".

a immediately notify the Bank and its Shariah committee of the fact

$b$ immediately cease from carrying on such business, affair or activity and from taking on any other similar business, affair or activity

c within thirty days of becoming aware of such non-compliance or such further period as may be specified by the Bank, submit to the Bank a plan on the rectification of the non-compliance" (emphasis added).

As a sanction to the obligation to carry out the above prescribed duties, section 28(4) IFSA provides as follows:

\footnotetext{
"Any person who contravenes subsection (1) or (3) commits an offence and shall, on conviction, be liable to imprisonment for a term not exceeding eight years or to a fine not exceeding twenty-five million ringgit or to both" (emphasis added).
}

SAC is a council established by BNM pursuant to section 51 CBMA. Section 51(1) CBMA (Establishment of SAC) provides:

"The Bank may establish a SAC on Finance which shall be the authority for the ascertainment of Islamic law for the purposes of Islamic financial business".

The word 'Bank' here refers to the Central Bank of Malaysia or in Bahasa Malaysia is called 'BNM' (section 2 CBMA).

The SAC shall be the authority for the ascertainment of Islamic Law for the purpose of Islamic banking/financial business (section 51 CBMA). 
It is a duty of the BNM and IFIs to consult the SAC pursuant to sections 55(1) and 55(2) CBMA in respect of Islamic banking and financial business and conducting its affairs. Section 55(1) CBMA states:

"The Bank shall consult the SAC on any matter-

a relating to Islamic financial business

$b$ for the purpose of carrying out its functions or conducting its business or affairs under this Act or any other written law in accordance with the Shariah, which requires the ascertainment of Islamic law by the Shariah Advisory Council".

The purpose of consulting, referring and seeking advice from the SAC is to make sure that the Islamic banking and financial business and its affairs are conducted in accordance with the requirements of Shariah (section 55(2) CBMA). Section 55(2) CBMA provides:

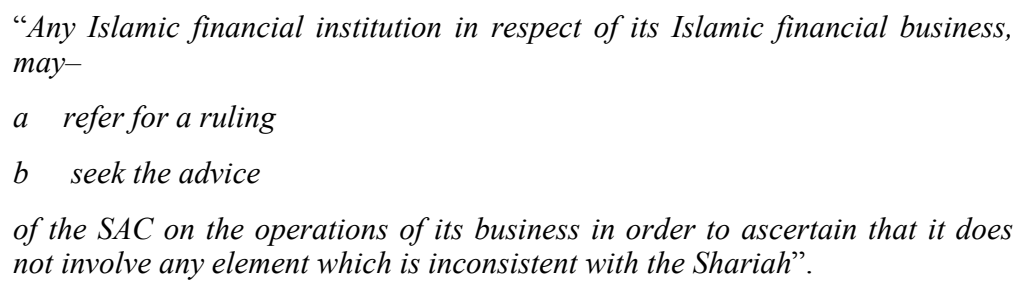

Apart for sections 51 and 55, sections 56(1), 57 and 58 CBMA also prescribes that the rulings and advice of the SAC shall bind the IFIs, the BNM, the Shariah Committee, the court of law and the arbitrators on matters pertaining to Islamic financial matters.

Section 56(1) (reference to SAC for ruling from court or arbitrator) CBMA provides:
"Where in any proceedings relating to Islamic financial business before any court or arbitrator any question arises concerning a Shariah matter, the court or the arbitrator, as the case may be, shall-
a take into consideration any published rulings of the SAC; or
$b$ refer such question to the SAC for its ruling" (emphasis added).

Section 57 CBMA (Effect of Shariah rulings) states as follows:
"Any ruling made by the SAC pursuant to a reference made under this Part shall be binding on the Islamic financial institutions under section 55 and the court or arbitrator making a reference under section 56" (emphasis added).

While section 58 CBMA (SAC ruling prevails) provides:
"Where the ruling given by a Shariah body or committee constituted in Malaysia by an Islamic financial institution is different from the ruling given by the Shariah Advisory Council, the ruling of the Shariah Advisory Council shall prevail' (emphasis added).

Thus, pursuant to the above provisions, the rulings and advice of the SAC shall bind the IFIs, the court of law, the arbitrator and the Shariah committee. In other words, the new provision inserted in the CBMA in relation to the SAC, serve as an ouster clause to oust any jurisdiction and power of the court of law, any other Shariah committee of the IFIs and any other persons to challenge the rulings and advice of the SAC in respect of Islamic financial business and affairs (Md. Dahlan and Aljunid, 2010). 
Apart from complying with Shariah and the SAC, the institution carrying out Islamic banking/financial business must follow the standards set out by the BNM and the SAC. This is mentioned in section 29. Failure to carry out this obligation will trigger certain punishment pursuant to section 29(6), which provides:

"Any person who fails to comply with any standards specified under subsection (1), commits an offence and shall, on conviction, be liable to imprisonment for a term not exceeding eight years or to a fine not exceeding twenty-five million ringgit or to both."

Similarly, all persons, including the IFIs, are duty bound to comply with the directions (written circulars, guidelines and notices) of the BNM on any Shariah matter relating to the Islamic banking/financial business. These directions are made in accordance with the advice of the SAC. Any person who fails to comply with any of these directions, commit an offence and shall, on conviction, be liable to a fine not exceeding three million ringgit (section 59(1)(2)(3) of the CBMA).

In addition to the above, the IFIs must also comply with the advice of its internal Shariah Committee. This is spelt out under section 30(1) of the IFSA.

It is noteworthy that the IFIs must also establish their own internal Shariah Committee to advise its business, affairs and activities in order to ensure that it complies with Shariah (section 30(1) of the IFSA). The duties and functions that the Shariah Committee carries out must also be consistent with the standards prescribed by the BNM (section 32 of the IFSA).

\section{Cases on the superiority and hegemony of the SAC}

The superiority and hegemony of the SAC over the court, the IFIs, the arbitrator and the Shariah Committee in relation to the Islamic banking/financial business and affairs has been given judicial support and recognition by recent cases namely:

$1 \quad$ Bank Islam Malaysia Bhd lwn Rhea Zadani Corp Sdn Bhd dan lain-lain [2012] 10 MLJ 484 (High Court of Malaya at Kuala Lumpur);

2 Bank Muamalat Malaysia Bhd lwn Kong Sun Enterprise Sdn Bhd dan lain-lain [2012] 10 MLJ 665 (High Court of Malaya at Johor Bahru)

3 CIMB Islamic Bank Bhd v LCL Corp Bhd \& Anor [2012] 3 MLJ 869 (High Court of Malaya at Kuala Lumpur)

$4 \quad$ Kuwait Finance House (M) Bhd lwn Teknogaya Diversified Sdn Bhd dan lain-lain [2012] 9 MLJ 433 (High Court of Malaya at Kuala Lumpur)

$5 \quad$ Mayban Trustees Bhd v CIMB Bank Bhd and other appeals [2012] 2 MLJ 187 [2012] 6 MLJ 354 (Court of Appeal at Putrajaya)

6 Mayban Trustees Bhd v CIMB Bank Bhd and other appeals [2012] 6 MLJ 354 (Court of Appeal at Putrajaya)

$7 \quad$ Mohd Alias bin Ibrahim v RHB Bank Bhd \& Anor [2012] 1 ShLR 23; [2011] 3 MLJ 26 (High Court of Malaya at Kuala Lumpur)

$8 \quad$ Tan Sri Abdul Khalid bin Ibrahim v Bank Islam Malaysia Bhd [2012] 1 ShLR 1; [2012] 7 MLJ 597 (High Court of Malaya at Kuala Lumpur)

9 Tan Sri Abdul Khalid bin Ibrahim v Bank Islam Malaysia Bhd [2013] 3 MLJ 269 (Court of Appeal at Putrajaya)

10 Tan Sri Abdul Khalid bin Ibrahim v Bank Islam Malaysia Bhd and another suit [2009] 6 MLJ 416 (High Court of Malaya at Kuala Lumpur). 


\section{Liability and responsibility of the SAC}

In the opinion of the authors, despite the absolute power and immunity that the SAC has in Islamic banking/financial business and affairs and its hegemony and superiority, it is submitted that the SAC is still subject to a legal duty, not just under Shariah, to act fairly and reasonably in the exercise of their powers. In other words, if it is proven that the SAC fails to execute its statutory duties fairly and reasonably to the detriment of the customer stakeholders, the latter shall have a cause of action and locus standi against the SAC and are entitled to certain legal and equitable remedies. This contention is made on the following grounds:

- There exists a fiduciary duty on part of the SAC toward the public customer stakeholders in dispensing their public duties. For instance, in financing housing development projects, the public customers/stakeholders are the housing developers and the purchasers.

- There exists a legitimate expectation on part of the customer stakeholders against the SAC in that the SAC should exercise its statutory and/or prerogative powers conferred by the IFSA and CBMA in a fair and reasonable manner in dispensing its statutory duties for the benefit of its stakeholders (for example the housing developers and the purchasers).

- Even though the SAC has an absolute statutory power over the Islamic banking and financial business and affairs, this statutory power is not an unfettered one. This power is still subject to the principles of natural justice, equity, good faith and fairness.

\subsection{Fiduciary duty}

It is submitted that the duty of the SAC to exercise due care in exercising its duties under the IFSA and CBMA is a fiduciary one. The SAC should ensure that the outcome of its decision in Islamic banking/financial business and affairs would benefit the public customer stakeholders and should not cause any unnecessary and gratuitous problems to the customer stakeholders.

This duty is enunciated in Kerajaan Negeri Selangor \& Ors v Sagong bin Tasi \& Ors [2005] 6 MLJ 289 (Court of Appeal). In this case, the State Government of Selangor (the first defendant-owner of all un-alienated land in the state) was held liable to have acquired the land (Bukit Tampoi) occupied and belonging to the plaintiffs (aboriginal peoples) with the second defendant (UEM Berhad), third defendant (Malaysian Highway Authority) and fourth defendant (Federal Government), by depriving the plaintiffs' proprietary rights without adequate compensation in accordance with the Land Acquisition Act 1960 ('LAA'). Secondly, the defendants were liable for having unlawfully evicted the plaintiffs from their lands as the 14-day notice was unreasonable and insufficient, not being compliant with the LAA procedure. The defendants were also liable for trespass.

The first defendant had also breached their fiduciary duties in not having gazetted the un-gazetted area for the welfare and benefit of the plaintiffs as an aboriginal reserve area. They failed to gazette the area despite their knowledge and awareness that such 
non-gazetted area was also occupied and needed by the plaintiffs to carry out their customary practices.

The court held that the discretionary power of the State Authority or public body is not an unfettered one in light of its responsibility toward the welfare and in trust of its subjects (stakeholders). The exercise of the power must be in accordance with the law and for public good. Thus, it follows that they are fiduciary to the public.

The above principles are also found in Australian cases in Mabo No 2 (Mabo \& Ors $v$ State of Queensland \& Anor [1986] 64 ALR 1 and Wik People's v The State of Queensland \& Ors [1996] 187 CLR 1. In other parts of the commonwealth, this principle is also entrenched in many cases such as Premanchandra $v$ Major Montague Jayawickrema [1994] 2 Sri LR 90. In this case at page 105, GPS De Silva CJ when delivering the judgement of the Supreme Court of Sri Lanka said:

\footnotetext{
"There are no absolute or unfettered discretions in public law; discretion are conferred on public functionaries in trust for the public, to be used for the public good, and the propriety of the exercise of such discretions is to be judged by reference to the purposes for which they were so entrusted" (emphasis added).
}

In Malaysia, the above principle had also been adopted in Pengarah Tanah dan Galian Wilayah Persekutuan v Sri Lempah Enterprise Sdn. Bhd [1979] 1 MLJ 135 and Savrimuthu v Public Prosecutor [1987] 2 MLJ 173.

It is submitted, a fiduciary duty exists on part of the SAC in exercise of its statutory powers in Islamic banking and financial business and affairs. Following this, it must obtain the requisite advice and views from all relevant parties (including the consumers and purchasers' associations) and comply with the advice and views before approving any proposed Islamic banking and financial products. The SAC should also decide prudently in a reasonably manner supported by the advice of the appropriate segments of society before approving any Islamic banking and financial products. Even though based on the authors' view there has not yet any case law pointing to this position, it is submitted the SAC is under a fiduciary duty in carrying out public duties, for instance in making decision in approving Islamic banking/financial products.

\subsection{Legitimate expectation}

Before elaborating on the above sub-heading, the authors would like to raise a question: Whether the aggrieved customer stakeholders in Islamic banking and financial business and affairs has a legitimate expectation against the SAC that the SAC would approve suitable, equitable, well-balanced and all-inclusive Islamic banking and financial products up to the extent of protecting the rights and interests of the customer stakeholders as well?

The principle behind the doctrine of legitimate expectation is founded on the duty to act fairly as a necessity element or concomitant of good governance or good administration (Wade and Forsyth, 2000; Fiadjoe, 1999). The doctrine of legitimate expectation was initially recognised by Lord Denning in Schmidt $v$ Secretary of State for Home Affairs [1969] 2 Ch 149 (CA) to denote something less than a right which may nevertheless be protected by the principles of natural justice; or an expectation of receiving some benefit or privilege to which the individual has no right. 
In the Privy Council case of Attorney-General of Hong Kong $v$ Ng Yuen Shiu [1983] 2 AC 629 (Privy Council (PC')), Ng Yuen Shiu an illegal immigrant challenged a deportation order. He contended that the Hong Kong government had previously given an undertaking that each case would be considered on its merits and that he was denied the opportunity of being heard. The PC held that $\mathrm{Ng}$ had a legitimate expectation that a certain procedure would be followed and that it was in the interest of good administration that the authorities should act fairly by implementing its stated policy. Lord Fraser said that 'legitimate expectation in this context is capable of including expectations which go beyond enforceable legal rights, provided they have some reasonable basis'. His Lordship identified three practical questions underlying all legitimate expectation cases. They are:

- To what has the authority committed itself?

- Has the authority acted unlawfully in respect of its commitment?

- What should the court do about it?

In Darahman bin Ibrahim \& Ors v Majlis Mesyuarat Kerajaan Negeri Perlis \& Ors [2008] 4 MLJ 309, at page 333, the Court of Appeal said that where an applicant can demonstrate that a legitimate expectation has arisen, he has a powerful argument against a public body which has otherwise acted pursuant to the discretionary powers or duties lawfully conferred upon it. It is germane to state that a legitimate expectation in its procedural form arises where there has been a failure to follow an agreed or customary, process of consultation. In the main, it is concerned about the quality of the decisionmaking process. The latter is called substantive legitimate expectation, while the former is known as procedural legitimate expectation.

In $\mathrm{Dr}$ Michael Jeyakumar Devaraj $v$ Ketua Pengarah Unit Penyelarasan Pelaksanaan di Jabatan Perdana Menteri \& Ors [2011] 6 MLJ 824 (High Court at Kuala Lumpur), the argument of legitimate expectation was successfully pleaded by the applicant and the court agreed that legitimate expectation arose in the circumstance of this case. In this case, the court held the application of the applicant being a Member of Parliament for the Sungai Siput constituency for leave for judicial review against the decision of the respondents (being the Director General of the Implementation Coordination Unit (ICU) of the Prime Minister's Department and the Director of the Perak State Development) who rejected the applicant's application for funds from the special constituency allowance for schools, orphanage and aid to the orang asli was allowed by the court. The court stated that the exercise of discretion on part of the respondents in dealing with the application of the applicant may well be based on policy considerations within the management prerogative but the respondents evidently had acted capriciously and in breach of the legitimate expectation that they owed to the applicant, with bias and/or for improper purpose, had failed to take into account relevant factors and had taken into account irrelevant factors.

In Sipadan Dive Sdn Bhd \& Ors v The State government of the State of Sabah [2011] 3 MLJ 357 (High Court of Borneo at Kota Kinabalu) again the court found that legitimate expectation existed on part of the State government toward the plaintiffs. In this case, the plaintiffs were awarded by the court compensation or damages as the defendant being the state government had breached the plaintiffs' legitimate expectation in that the plaintiffs were not given reasonable notice to wind down their business that had resulted in the plaintiffs' losses owing to the demolition of the plaintiffs' buildings by the defendant and 
losses of the plaintiffs' equitable or proprietary interests in the plaintiffs' diving resorts. The legitimate expectation was also created on the request of the defendant that the fifth plaintiff was to prepare a master plan proposed for Pulau Sipadan. Further, legitimate expectation existed when the plaintiffs were allowed to continue operating on Sipadan Island even after Malaysia had gained sovereignty over the island. Evidence which the plaintiffs relied on is that the defendant actively used the presence of the plaintiffs on the island to promote Malaysia's tourism industry and to argue Malaysia's sovereignty rights over the island at the International Court of Justice (ICJ).

In $R v$ Secretary of State for the Home Department, ex parte Khan [1985] 1 All ER 40 (Court of Appeal, Civil Division), Watkins LJ said at page 41 as follows:

\begin{abstract}
"where a member of the public affected by a decision of a public authority had a legitimate expectation based on a statement or undertaking by the authority that it would apply certain criteria or follow certain procedure in reaching its decision, the authority was under a duty to follow those criteria or procedures" (emphasis added).
\end{abstract}

The case of $R v$ North and East Devon Health Authority, ex parte Coughlan (Secretary of State for Health and another intervening) [2000] 3 All ER 850 provides an example of what amounts to substantive legitimate expectation. In this case, a tetraplegic victim of a road accident in 1993 was housed in a health institute called Mardon House, a NHS facility for the long term disabled. It was represented to the victim by the health authority that he could stay at Mardon House 'for as long as they chose'. When the health authority decided to close Mardon House without providing alternative suitable accommodation, the Court of Appeal held that, in view of the representation, a breach of this legitimate expectation amounted to an abuse of power and the substantive promise was upheld.

In Toh Huat Khay v Lim A Chang (in his capacity as the executor of the estate of Toh Hoy Khay, deceased) [2010] 4 MLJ 312 (Federal Court at Putrajaya), legitimate expectation existed on part of the State Authority to ensure that the requirements of the law relating to the land transfer must be observed and complied with. The court also held that owing to this the State Authority breached its fiduciary duty. In this case, the State Authority consented to a land transfer despite the fact that it is still subject to restrictions in interests of 10 years prohibition of sale, from the date of alienation. Owing to this, the court held that the transfer was null and void, despite there being a consent given by the State Authority. It follows that, according to the court, such a transfer could not give any indefeasibility of title to the transferee as the registration of the land was procured by means of an insufficient or void instrument pursuant to section 340(2)(b) of the NLC.

Thus, following the above legal principle and courts' decision, in the submission of the authors, the aggrieved customer stakeholders in Islamic banking and financial products have a legitimate expectation, procedurally and substantively, that the SAC, as a public authority, should have approved or should approve suitable Islamic banking products that can also give reciprocal protection to customer stakeholders' rights and interests.

It is submitted that the foundation for the creation of procedural and substantive legitimate expectation of the public toward the SAC is derived from the objectives of the Shariah (maqasid shariah) itself, i.e., to protect the rights and interests of the people in term of their life, wealth and the inherent responsibility of a public authority to exercise their duties for social justice, public good and public welfare and well-being. 
From the above cases and discussion, the conclusion is that the SAC owes a fiduciary duty and that its subjects (customer stakeholders) have procedural and substantive legitimate expectation that it (the SAC) when approving Islamic banking and financial products would approve suitable, equitable, fair and all-inclusive products in a professional, fair and reasonable manner for the reciprocal benefits of the customer stakeholders.

\subsection{Ouster clauses}

There are cases that held ouster clause given to public authority is ineffective as against the power of the court for judicial review or other equitable relief. The immunity given by the ouster clause is shattered if the public authority has done some acts which is wrong in law. This proposition is supported by the following cases:

1 Re Racal Communication [1981] 2 AC 374

2 Anisminic Ltd v Foreign Compensation Commission [1969] 2 AC 147

3 Council of Civil Service Union v Minister for the Civil Service [1985] AC 374.

The ground on which relief and remedies are given to the aggrieved parties has been succinctly summarised by Lord Diplock in Council of Civil Service Union under three developed heads, viz., 'illegality', irrationality' and 'procedural impropriety'.

Christopher Leong, President of the Malaysian Bar at the opening of the Legal Year 2014 at Dewan Sri Siantan, Perbadanan Putrajaya on 11 January, 2014 said that (Leong, 2014):

"Ouster clauses are obnoxious, as they purport to confer absolute powers on the Executive and attempt to render the Judiciary subordinate. They are contrary to the doctrine of separation of powers that underpins the Federal Constitution and that is essential to, and inherent in, a modern democracy that professes and abides by the rule of law. Ouster clauses also undermine the rights of aggrieved parties to access justice.

The Judiciary has in some cases stood up and denuded the efficacy of ouster clauses. One example is the landmark Court of Appeal case of Syarikat Kenderaan Melayu Kelantan. This decision is an affirmation of the oath that all judges take upon assuming office, that is, to preserve, protect and defend the Constitution, and so may this continue" (emphasis added).

In Syarikat Kenderaan Melayu Kelantan Bhd v Transport Workers' Union [1995] 2 MLJ 317 (Court of Appeal) at pages 336-344, Gopal Sri Ram JCA said:

"The next topic that requires consideration is the ability of the High Court to exercise judicial review over awards of the court in the face of a privative clause. The attempt by Parliament to exclude judicial review is, in this instance, expressed in $\mathrm{s} 33 \mathrm{~B}(1)$ of the Act ... a preponderance of Malaysian authority, when dealing with the precursor to $\mathrm{s} 33 \mathrm{~B}(1)$, favoured the view that the High Court's supervisory jurisdiction to quash an administrative decision for an error of law not going to jurisdiction was not excluded by the ouster clause...

In my opinion, the true principle may be stated as follows. An inferior tribunal or other decision making authority, whether exercising a quasijudicial function or purely an administrative function, has no jurisdiction to commit an error of law. Henceforth, it is no longer of concern whether the error of law is jurisdictional or not. If an inferior tribunal or other 
public decision-taker does make such an error, then he exceeds his jurisdiction. So too is jurisdiction exceeded, where resort is had to an unfair procedure...or where the decision is reached is unreasonable, in the sense that no reasonable tribunal similarly circumstanced would have arrived at the impugned decision.

It is neither feasible nor desirable to attempt an exhaustive definition of what amounts to an error of law, for the categories of such an error are not closed. But it may be safely said that an error of law would be disclosed if the decisionmaker asks himself the wrong decision or takes into account irrelevant considerations or omits to take into account relevant considerations... or if he misconstrues the terms of any relevant statute, or misapplies or misstates a principle of the general law.

Since an inferior tribunal has no jurisdiction to make an error of law, its decision will not be immunised from judicial review by an ouster clause however widely drafted" (emphasis added).

\section{Conclusion and recommendations}

The authors are of the view that in approving Islamic banking and financial products, if proven that the products are not suitable and unfair to the customer stakeholders and that owing to this reason the customer stakeholders become aggrieved, the aggrieved customer stakeholders have a good cause of action and locus standi against the SAC if the latter had acted unreasonably, unfairly, in breach of natural justice and the legitimate expectation of the customer stakeholders and is mala fide. In this regard, the aggrieved customer stakeholders may claim for appropriate compensation and damages for all the calamities that have occurred owing to the failure of the SAC to carry out their statutory duties reasonably.

It is submitted that an amendment should be made to the IFSA and CBMA to the effect of imposing an obligation on the SAC to be bound by the principles of administrative law and tortuous law in the decision-making process in considering and approving Islamic banking and financial products in Malaysia. Further, the SAC should also be responsible for all the decisions made and no immunity should be given to them if proven it has acted unreasonably, unfairly, in breach of natural justice and the legitimate expectation of the customer stakeholders and mala fide in carrying out their public duties.

Apart from the legislative proposals above, it is the hope of the authors, there will be, in the near future, aggrieved customer stakeholders for an instance the failed housing projects' purchasers or housing developers who may realise and with proof that their miserable plights are owing to the failure of the SAC to observe the duty to act fairly and reasonably in the exercise of its statutory power in approving Islamic home financial products to take certain legal actions against the defaulting SAC for some judicial remedies. Thus, the legal perimeter on the responsibility and liability in implementing public duties by the public bodies in Malaysia can be further defined and expounded by the guardian of the law itself.

Finally, the ouster clause conferring immunity on the SAC, in the submission of the authors, is ineffective if the SAC, as a public authority in exercising its statutory duties, has transgressed the law, i.e., has acted unreasonably, unfairly, in breach of natural justice and the legitimate expectation of the customer stakeholders and mala fide in carrying out its public duties. 


\section{References}

Anisminic Ltd v Foreign Compensation Commission [1969] 2 AC 147.

Attorney-General of Hong Kong v Ng Yuen Shiu [1983] 2 AC 629 (Privy Council).

Bank Islam Malaysia Bhd lwn Rhea Zadani Corp Sdn Bhd dan lain-lain [2012] 10 MLJ 484 (High Court of Malaya at Kuala Lumpur).

Bank Muamalat Malaysia Bhd lwn Kong Sun Enterprise Sdn Bhd dan lain-lain [2012] 10 MLJ 665 (High Court of Malaya at Johor Bahru).

Central Bank of Malaysia Act 2009(Act 701).

CIMB Islamic Bank Bhd v LCL Corp Bhd \& Anor [2012] 3 MLJ 869 (High Court of Malaya at Kuala Lumpur).

Council of Civil Service Union v Minister for the Civil Service [1985] AC 374.

Darahman bin Ibrahim \& Ors v Majlis Mesyuarat Kerajaan Negeri Perlis \& Ors [2008] 4 MLJ 309 (Court of Appeal).

Dr Michael Jeyakumar Devaraj v Ketua Pengarah Unit Penyelarasan Pelaksanaan di Jabatan Perdana Menteri \& Ors [2011] 6 MLJ 824 (High Court of Malaya at Kuala Lumpur).

Fiadjoe, A. (1999) Commonwealth Caribbean Public Law, 2nd ed., Cavendish Publishing Limited, London.

Islamic Financial Services Act 2013 (Act 759).

Kerajaan Negeri Selangor \& Ors v Sagong bin Tasi \& Ors [2005] 6 MLJ 289 (Court of Appeal).

Kuwait Finance House (M) Bhd lwn Teknogaya Diversified Sdn Bhd dan lain-lain [2012] 9 MLJ 433 (High Court of Malaya at Kuala Lumpur).

Leong, C. (2014) 'Speech by Christopher Leong, President, Malaysian Bar at the opening of the legal year 2014 (Dewan Sri Siantan, Perbadanan Putrajaya, 11 January 2014)', Malayan Law Journal, Vol. 1, pp.ii-xiv.

Mabo No 2 (Mabo \& Ors v State of Queensland \& Anor [1986] 64 ALR 1 and Wik People's v The State of Queensland \& Ors [1996] 187 CLR 1.

Mayban Trustees Bhd v CIMB Bank Bhd and other appeals [2012] 2 MLJ 187; [2012] 6 MLJ 354 (Court of Appeal at Putrajaya).

Md. Dahlan, N.H. and Aljunid, S.Z.S.A.K. (2010) 'Shariah and legal issues in the bay' Bithaman al-Ajil (BBA): a viewpoint', Malayan Law Journal, Vol. 6, pp.lxxv-cxiii.

Md. Dahlan, N.H. and Aljunid, S.Z.S.A.K. (2011) 'Shariah and legal issues in house buying in Malaysia: the legality of bay' Bithaman al-Ajil ('BBA') with special reference to abandoned housing projects', Pertanika Journal of Social Sciences \& Humanities, Vol. 19, No. 2, pp.349-361.

Mohd Alias bin Ibrahim v RHB Bank Bhd \& Anor [2012] 1 ShLR 23; [2011] 3 MLJ 26 (High Court of Malaya at Kuala Lumpur).

Pengarah Tanah dan Galian Wilayah Persekutuan v Sri Lempah Enterprise Sdn. Bhd [1979] 1 MLJ 135 and Savrimuthu v Public Prosecutor [1987] 2 MLJ 173 (High Court of Malaya at Kuala Lumpur).

Premanchandra v Major Montague Jayawickrema [1994] 2 Sri LR 90.

$R v$ North and East Devon Health Authority, ex parte Coughlan (Secretary of State for Health and another intervening) [2000] 3 All ER 850.

$R v$ Secretary of State for the Home Department, ex parte Khan [1985] 1 All ER 40 (Court of Appeal, Civil Division).

Re Racal Communication [1981] 2 AC 374.

Schmidt v Secretary of State for Home Affairs [1969] 2 Ch 149 (CA).

Sipadan Dive Sdn Bhd \& Ors v The State Government of the State of Sabah [2011] 3 MLJ 357 (High Court of Borneo at Kota Kinabalu). 
Syarikat Kenderaan Melayu Kelantan Bhd v Transport Workers' Union [1995] 2 MLJ 317 (Court of Appeal).

Tan Sri Abdul Khalid bin Ibrahim v Bank Islam Malaysia Bhd [2012] 1 ShLR 1; [2012] 7 MLJ 597 (High Court of Malaya at Kuala Lumpur).

Tan Sri Abdul Khalid bin Ibrahim v Bank Islam Malaysia Bhd [2013] 3 MLJ 269 (Court of Appeal at Putrajaya).

Tan Sri Abdul Khalid bin Ibrahim v Bank Islam Malaysia Bhd and another suit [2009] 6 MLJ 416 (High Court of Malaya at Kuala Lumpur).

Toh Huat Khay $v$ Lim A Chang (in his capacity as the executor of the estate of Toh Hoy Khay, deceased) [2010] 4 MLJ 312 (Federal Court at Putrajaya).

Wade, W. and Forsyth, C. (2000) Administrative Law, 8th ed., Oxford University Press, Oxford. 